Pak. j. sci. ind. res. Ser. B: biol. sci. 2021 64B(2) 167-174

\title{
Determination of Nutritional Status of Some Vegetables Grown with Different Water Resource Applications in Sargodha, Pakistan
}

\author{
Kafeel Ahmad $^{\text {a }}$, Asma Ashfaq ${ }^{\mathrm{a}}$, Zafar Iqbal Khan ${ }^{\mathrm{a} *}$, Hunayun Bashir ${ }^{\mathrm{ab}}$, Mudasra Munir ${ }^{\mathrm{a}}$, \\ Ifra Saleem Malika ${ }^{a}$, Khalid Nawaz ${ }^{c}$, Hafsa Memoona ${ }^{d}$, Madiha Sana ${ }^{d}$, Ijaz Rasool Noorka ${ }^{e}$, \\ Mahpara Shahzadie, Naunain Mehmood ${ }^{\mathrm{f}}$ and Hira Muqaddas \\ ${ }^{a}$ Department of Botany, University of Sargodha, Sargodha, Pakistan \\ ${ }^{b}$ Institute of Molecular Biology and Biotechnology, The University of Lahore, Lahore, Pakistan \\ ${ }^{c}$ Department of Botany, University of Gujrat, Gujrat, Pakistan \\ ${ }^{\mathrm{d}}$ Department of Zoology, Lahore College for Women Univerisity, Lahore, Pakistan \\ ${ }^{e}$ Department of Plant Breeding and Genetics, Ghazi University, Dera Ghazi Khan, Pakistan \\ ${ }^{\mathrm{f}}$ Department of Zoology, University of Sargodha, Sargodha, Pakistan \\ 'Department of Zoology, The Women University Multan, Multan, Pakistan
}

(received March 13, 2018; revised January 16, 2019; accepted January 17, 2019)

\begin{abstract}
Proximate and nutritional concentrations of some vegetables irrigated with different types of water were determined in present study. Allium fistulosum showed highest concentrations of $\mathrm{N}$ and $\mathrm{P}$ at site 3 and site1, respectively. Highest ash concentration in Trigonella foenum-graecum demonstrated high mineral concentration of this vegetable. The crude protein contents ranged from $15.38 \%$ to $26.19 \%$ and crude fiber contents ranged from $12.81 \%$ to $16.73 \%$ in all vegetables. The tannins and saponins contents showed significant $(\mathrm{P}<0.05)$ result among all vegetables at all sites. Proximate and nutrient analysis of cultivated vegetables can help us to determine the health benefits achieved from their use in marginal communities.
\end{abstract}

Keywords: nitrogen, potassium, phosphorus, crude protein, crude fiber, vegetables

\section{Introduction}

Vegetables are important means of nutrients particularly in rural zones, where they contributes significantly to protein, minerals, vitamins, filaments and different supplements which are normally hard to come by diets (Mohammed and Sharif, 2011). Vegetables are consisting of crude material for setting up a variety of sustenance, in this way improving nutrition (Butnariu and Chimie, 2006).

Proximate and nutrient investigation of vegetables assumes a critical part in evaluating their nutritious status (Pandey et al., 2006). It provides information on ash content, crude protein and crude fibre etc. Ash is the inorganic residue left over after water and organic matter and can be removed by heating, which gives information about the total amount of minerals in food. In the presence of $\mathrm{N}$, soil have better capacity to hold essential elements because positive ions holding ability of soil increased by N (Epstien et al., 1976). Certain crude substances which required at specific limits and

*Author for correspondence; E-mail: Zafar. Khan@uos.edu.pk are growth regulators are known as nutrients (Parveen et al., 2006).

Already, various studies found that water rich with significant sources, for example, natural matter, macro and microelements that needed by the vegetables for ripeness and fertility of soil (Kiziloglu et al., 2008). Different specialists discovered wastewater utilized for irrigation supply $\mathrm{N}, \mathrm{K}$ and $\mathrm{P}$ to vegetables and soil, in this manner expanding yields and quality (Rusan et al., 2007). It has been accounted for that vegetables contain protein, vitamins and minerals required in food; and additionally roughage which advance assimilation and avert obstruction. $4-10 \%$ weight of young leaves consisting proteins, while in more old leaves the rate is just 1-2\% (Aliyu, 2006). The potassium level of leafy vegetable is great in the control of diuretic and hypertensive muddling (George, 2003).

These vegetables however contain anti-nutritional components that can influence the accessibility of the nutrients. Anti-nutritional variable is known to hinder with metabolic procedures such that development and 
bioavailability of nutrients are negatively affected (Abara, 2003; Binta and Khetarpau, 1997). Proximate (ash, crude fibre, crude protein and ether extract), nutritional (N, P, K) and anti-nutritional (Tannins, saponins, alkaloids, terpenes) were determined in the present study in order to know the nutritional status of some vegetables.

\section{Materials and Methods}

Study area. Study area was Sargodha which occupies fifth position in the cities found in Punjab. In North East side of Pakistan Sargodha is situated. Its latitude is $32,08369\left(32.5^{\prime}\right.$ to $\left.0.960 \mathrm{~N}^{\prime \prime}\right)$., its longitude is $72,6711\left(7240^{\prime} 15.960^{\prime \prime} \mathrm{E}\right)$ and its altitude is $193 \mathrm{~m}$. On its western and northern sides the river Jhelum flows and river Chenab flows on its eastern side. Sargodha is known as city of Eagles, the largest airbase PAF Mushaf which is famous for air warriors is found here. In summer the average temperature in day time reach up to $35^{\circ} \mathrm{C}$ and drops down to $27^{\circ} \mathrm{C}$, in night time. In the month of July the temperature reach to maximum till $43{ }^{\circ} \mathrm{C}\left(109^{\circ} \mathrm{F}\right)$ and in December the lowest recorded temperature $14{ }^{\circ} \mathrm{C}$. Six most common vegetables at three sites were chosen for investigation namely, $C$. sativum (Coriandrum sativum L.), spring A. fistulosum (Allium fistulosum L.), fenugreek leaves (Trigonella foenum-graecum L.), D. carota (Daucus carota L.), $R$. sativus (Raphanus sativus L.) and B. rapa (Brassica rapa L.). The collection of samples was done from December 2014 to March 2015.

Vegetable collection. Eighteen samples of each vegetable were taken from three sites; one was supplied with groundwater, second with canal water and third with wastewater. Wastewater is a combination of domestic Sewage water and non-sewage water. The domestic sewage includes all wastewater generated by home dwellings, public restrooms, hotels, hospitals. Non-sewage water includes water from floods (storm water), runoff water from car garages and cleaning centers.

Deionized water was used for washing samples in order to evacuate soil and stored for further examinations.

Proximate analysis. Crude protein (CP), ether extracts (EE), Crude fiber (CB) and ash content (AC) were analyzed using the method of AOAC (1996).

Ash. Take $1 \mathrm{~g}$ of sample, burn it at $600{ }^{\circ} \mathrm{C}$ for six hours. Burn all the organic contents. Ash contents were detected by using formulae (AOAC, 1996).
Ash $\%=\frac{\text { weight of ash }}{\text { weight of sample }} \times 100$

Crude protein. Percentage of crude protein was analyzed (AOAC, 1996).

Crude protein $=\mathrm{N}(\%) \times 6.25$

Crude fibre. The first step was that samples were digested with $1.25 \%$ sulphuric acid and then with $1.25 \%$ sodium hydroxide solution and filtered. The filtrate was then weighed and heated at $55^{\circ} \mathrm{C}$ in a muffle furnace till the remainder became white. Crude fibre percentage was calculated (AOAC, 1996).

Crude fibre $(\%)=\frac{\text { weight loss in ignition }(\mathrm{g})}{\text { weight of sample }(\mathrm{g})} \times 100$

Determination of macronutrients. Nitrogen. In order to determine the percentage of nitrogen, Kjeldahl's method was used (AOAC, 1990). Concentrated sulphuric acid and digestion tablets were mixed with the samples for approximately 2-3 $\mathrm{h}$ until the material became colorless. In order to dilute the sample, it was the mixed with $10 \mathrm{~mL}$ of $40 \%$ sodium hydroxide and $250 \mathrm{~mL}$ distilled water. In the end, ammonia released was then collected in $2 \%$ boric acid solution and titrated in 0.1 $\mathrm{N}$ sulphuric acid. The indicator used was methyl red resulting in golden brown colour at the end of process. Percentage of nitrogen was calculated by using the following formula:

Nitrogen $\%=$ Volume of $0.1 \mathrm{~N} \mathrm{H}_{2} \mathrm{SO}_{4}$ $\times$ Volume of dilution $\times 0.0014 \times 100$

Weight of sample $(\mathrm{g}) \times$ Volume of dilution $(\mathrm{mL})$

Determination of phosphorus. Phosphorus was determined colorimetrically (Chapman and Pratt, 1961).

Determination of potassium. Potassium was determined according to Jackson (1959) using flame photometer (Jenway model PFP7).

Determination of anti-nutrients. Tannin, terpenes, alkaloids and saponins were determined.

Estimation of tannins. An aliquot of the sample extract containing not more than $0.5 \mathrm{mg}$ of tannic acid was used and the percentage of tannin was determined.

Determination of terpenes. Terpenes were determined by using gas chromatograph-mass spectrometer (GCMS) (Hewlett-Packard HP59822B, Palo Alto, California) (Kjeldsen et al., 2003). 
Determination of saponin. $0.5 \mathrm{~g}$ of the sample was added to $20 \mathrm{~mL}$ of $1 \mathrm{NHCl}$ and was boiled for $4 \mathrm{~h}$. After cooling it was filtered and $50 \mathrm{~mL}$ of petroleum ether was added to the filtrate for ether layer and evaporated to dryness. $5 \mathrm{~mL}$ of acetone ethanol was added to the residue and $0.4 \mathrm{~mL}$ of each was taken into 3 different test tubes. $6 \mathrm{~mL}$ of ferrous sulphate reagent was added into them followed by $2 \mathrm{~mL}$ of conc. $\mathrm{H}_{2} \mathrm{SO}_{4}$. It was thoroughly mixed after $10 \mathrm{~min}$ and the absorbance was taken at $490 \mathrm{~nm}$ (Cowan, 1999).

Determination of alkaloid. For alkaloid determination, a known weight of the plant material was extracted with $20 \%$ acetic acid in ethanol. The sample was filtered and then concentrated, using a water bath, to one-quarter of the original volume. Concentrated ammonium hydroxide was then added drop wise to the extract until precipitation was complete. The whole solution was allowed to settle and the precipitate was collected by filtration and weighed (Obadoni and Ochuko, 2001; Harbone, 1973).

Statistical analysis. All data were subjected to statistical analysis by using SPSS 20 for one way ANOVA. The differences between the mean concentrations were found at $0.001,0.01$ and 0.05 probability levels (Steel and Torrie, 1980).

\section{Results and Discussion}

Nitrogen. $N$ concentration showed significant $(\mathrm{P}<0.05)$ variation in all vegetables (Table 1). Highest $\mathrm{N}$ concentration was found in A. fistulosum (1.97) at site3 and lowest in D. carota (1.53) at site2 (Table 2). The low $\mathrm{N}$ levels may be ascribed to their development on uncultivated land, since $\mathrm{N}$ in vegetable is because of nitrate treatment used to push development of the plant (Sarojini, 1998). Results of N content for S. nigrum and $S$. biafrae reported by Lola (2009) were lower than the present $\mathrm{N}$ concentrations. Highest value $\mathrm{N}$ was seen at site 3 during present study. Macronutrients are thought to be essential in human nourishment (Ibang and Okon, 2009)

Phosphorus. $\mathrm{P}$ concentration showed significant $(\mathrm{P}<0.05)$ variation in all vegetables except in $A$. fistulosum (Table 1). Highest P concentration was found in A. fistulosum at site 1 and lowest in T. foenumgraecum at site-I (Table 2). Useful and unwanted chemical contents in vegetables essentially influenced by agrotechnical measure, chemical composition of water, soil fertility and in addition climate conditions (Takebe et al., 1995). Agbaire (2011) reported lower concentration of $\mathrm{P}$ in some local vegetables of Nigeria as compared to present study.

Potassium. K concentration showed significant $(\mathrm{P}<0.05)$ variation in all vegetables except in $A$. fistulosum and $R$. sativus (Table 1). Highest $\mathrm{K}$ concentration was found in D. carota at site 3 and lowest in B. rapa at site2 (Table 2). Concentrations of $\mathrm{K}$ were in the range 1.36-1.58. FNIC (2011) also suggested concentrations (mg/Kg) of $\mathrm{K}$ in some vegetables as; cabbage (147), broccoli (229), D. carota (183), Chinese cabbage (268) and spinach (167). Emmanuel et al. (2011) reported much higher concentrations of $\mathrm{P}$ and $\mathrm{K}$ in Iringa district, Tanzania. During present study lower concentrations of $\mathrm{K}$ were found as compared to the concentration of $\mathrm{K}$ recorded by Osman (2004) in A. digitata pulp. The concentrations of $\mathrm{K}$ in present study were varied from $1.36 \%$ to 1.58 and lower than prescribed $18.0 \mathrm{mg} / \mathrm{g}$ every day necessity.

Ash. Ash contents showed significant $(\mathrm{P}<0.05)$ variation in all vegetables (Table 1). At site2, maximum ash contents were observed in T. foenum-graecum and the minimum in $R$. sativus (Table 3 ). Ash values are an evidence of the mineral status, these high values demonstrated that the vegetables are high in mineral concentration. Proof from epidemiological studies suggested that expanded fiber use may add to a lessening in the frequency of specific maladies like diabetes, coronary illness, colon tumor, hypertension, corpulence, and different digestive issue (Eriyamremu and Adamson, 1994). The ash content of present study were in the range $15.79-23.66 \%$, this was significantly higher than that of C. aconitifolius, T. occidentalis and A. cruentus (Kochhar, 1981). Present values of ash were above than the acceptable range for edible vegetables as suggested by Lucas (1988) and high to those obtained by Abidemi et al. (2009).

Crude protein (\%). Analysis of variance showed significant $(\mathrm{P}<0.05)$ variation in all vegetables except C. sativum (Table 1). The crude protein contents ranged from $15.38 \%$ to $26.19 \%$ in all vegetables. These values were higher than the value 1.20 and $1.93 \%$ reported for L. tetraxidicolie and B. rubra, respectively (Isa et al., 2006). Present values of crude protein were much higher as compared to findings of Ajala (2009). The higher crude protein contents as contrasted and results by Abidemi et al. (2009) makes them a good supply of vegetable protein which can provide animal protein. Vegetables containing high crude protein contents may 
Table 1. Analysis of variance of the parameters under different water resource applications in various vegetables

\begin{tabular}{|c|c|c|c|c|c|c|}
\hline Parameters & C. sativum & A. fistulosum & T. foenum-graecum & D. carota & R. sativus & B. rapa \\
\hline $\mathrm{N}$ & $0.05 * * *$ & $0.017 * * *$ & $0.006^{* * *}$ & $0.07 * * *$ & $0.03 * * *$ & $0.05 * * *$ \\
\hline $\mathrm{P}$ & $0.01 * * *$ & $0.01 \mathrm{~ns}$ & $0.007 * * *$ & $0.02 * * *$ & $0.009 * * *$ & $0.011 * *$ \\
\hline K & $0.03 * * *$ & $0.01 \mathrm{~ns}$ & $0.019 * * *$ & $0.04 * * *$ & $0.002 \mathrm{~ns}$ & $0.009 * * *$ \\
\hline Ash (\%) & $11.99 * * *$ & $6.33 * *$ & $39.6 * * *$ & $26.37 * * *$ & $25.29 * * *$ & $5.89 * * *$ \\
\hline C.P $(\%)$ & 71.99ns & $26.05^{* * *}$ & $1.85 * * *$ & $11.14 * * *$ & $1.89 * * *$ & $3.08 * * *$ \\
\hline C.F (\%) & $9.97 * * *$ & $2.17 * * *$ & $2.73 * * *$ & $4.02 * * *$ & $3.37 * * *$ & $0.59 *$ \\
\hline E.E $(\%)$ & $0.02 * * *$ & $0.02 * * *$ & $0.015 * * *$ & $0.006 * * *$ & $0.015 \mathrm{~ns}$ & $0.006^{* *}$ \\
\hline Terpenes (mg/Kg) & $75.44 * *$ & $109.8 * *$ & $1518 * * *$ & $616.8^{* * *}$ & $148 * *$ & $800.8 * * *$ \\
\hline Tannins (\%) & $0.05 * * *$ & $0.032 * *$ & $0.009 * *$ & $0.008 * *$ & $0.125^{* * *}$ & $0.048 * *$ \\
\hline Alkaloids (\%) & $0.007 * *$ & $0.001 \mathrm{~ns}$ & $0.003^{*}$ & $0.004 \mathrm{~ns}$ & $0.014 * *$ & $0.009 \mathrm{~ns}$ \\
\hline Saponins (\%) & $0.959 * * *$ & $2.29 * * *$ & $0.79 * * *$ & $0.79 * * *$ & $1.71 * * *$ & $0.048^{*}$ \\
\hline
\end{tabular}

$*, * *, * * *=$ Significant at $0.05,0.01$ and 0.001 levels; $\mathrm{ns}=$ non-significant

Table 2. Mineral composition of different vegetables

\begin{tabular}{llllllll}
\hline \hline Minerals & Study sites & C. sativum & A. fistulosum & T. foenum-graecum & D. carota & R. sativus & $B$. rapa \\
\hline \multirow{3}{*}{ N (\%) } & Site1 & $1.68 \pm 0.01$ & $1.83 \pm 0.13$ & $1.85 \pm 0.19$ & $1.83 \pm 0.14$ & $1.89 \pm 0.11$ & $1.76 \pm 0.22$ \\
& Site2 & $1.54 \pm 0.02$ & $1.87 \pm 0.17$ & $1.75 \pm 0.11$ & $1.53 \pm 0.11$ & $1.73 \pm 0.21$ & $1.57 \pm 0.12$ \\
& Site3 & $1.78 \pm 0.03$ & $1.97 \pm 0.21$ & $1.81 \pm 0.15$ & $1.77 \pm 0.12$ & $1.91 \pm 0.14$ & $1.81 \pm 0.14$ \\
& Site1 & $0.89 \pm 0.02$ & $0.81 \pm 0.04$ & $0.65 \pm 0.03$ & $0.76 \pm 0.21$ & $0.81 \pm 0.22$ & $0.85 \pm 0.02$ \\
P (\%) & Site2 & $0.83 \pm 0.01$ & $0.87 \pm 0.17$ & $0.78 \pm 0.02$ & $0.69 \pm 0.18$ & $0.89 \pm 0.26$ & $0.84 \pm 0.03$ \\
& Site3 & $0.79 \pm 0.07$ & $0.91 \pm 0.02$ & $0.75 \pm 0.06$ & $0.84 \pm 0.22$ & $0.78 \pm 0.15$ & $0.74 \pm 0.09$ \\
& Site1 & $1.52 \pm 1.3$ & $1.48 \pm 0.08$ & $1.53 \pm 0.14$ & $1.36 \pm 0.2$ & $1.52 \pm 0.17$ & $1.48 \pm 0.04$ \\
K (\%) & Site2 & $1.47 \pm 1.8$ & $1.51 \pm 0.13$ & $1.47 \pm 0.11$ & $1.56 \pm 0.1$ & $1.53 \pm 0.21$ & $1.36 \pm 0.08$ \\
& Site3 & $1.45 \pm 1.5$ & $1.56 \pm 0.11$ & $1.37 \pm 0.17$ & $1.58 \pm 0.5$ & $1.57 \pm 0.19$ & $1.43 \pm 0.14$ \\
\hline \hline
\end{tabular}

be used as high protein sources in some sustenance definitions. It has been accounted for that proteincalories hunger lacks is a central point dependable in nourishing pathology (Roger et al., 2005). Mean concentration of crude protein was recorded maximum at canal-water-irrigated-site. Plant sustenance that give more than $12.0 \%$ of its calorific quality from protein are considered great source of protein (Pearson, 1976). The consequences of this work demonstrated that sufficient protein is present in these vegetables and are great eating regimen for human being.

Crude fibre (\%). Crude fibre contents showed significant $(\mathrm{P}<0.05)$ variation in all vegetables $($ Table 1). The Crude fiber contents ranged from $12.81 \%$ to $16.73 \%$ in all vegetables (Table 3 ). These values are high as compared to crude fiber reported for $L$. tetraxidicolie and B. rubra (Isa et al., 2006). The American Dietetic Association (ADA) prescribed an intake of 20$35 \mathrm{~g}$ of fiber for every day (Duyff, 2002). Highest value ( $16.73 \%)$ of crude fiber was found at site3. Right now estimation of sustenance, crude fiber in the eating regimen is vital for absorption and for effective removal of wastes (Vadivel and Janardhanan, 2005).

Ether extract (\%). Analysis of variance showed significant effect of sites in all vegetables except $R$. sativus (Table 1). Highest concentrations of ether extract were found in $\mathrm{T}$. foenum-graecum at site 1 and lowest in R. sativus at site 2. Ether extract is a big source of energy which is utilized by individuals for protection and construction (Babayemi et al., 2009).

Terpenes $(\mathbf{m g} / \mathbf{K g})$. The terpenes content showed significant $(\mathrm{P}<0.05)$ result among all vegetables (Table $1)$. The terpenes contents among different vegetables ranged from $128 \mathrm{mg} / \mathrm{Kg}$ to $211 \mathrm{mg} / \mathrm{Kg}$ in (Table 4). Utilization of vegetables with moderate concentration of anti-nutrients is useful for human health (Mensah et al., 2008; Lewis and Elvin-Lewis, 1998).

Tannins (\%). The tannins contents showed significant $(\mathrm{P}<0.05)$ result among all vegetables (Table 1$)$. The tannins contents among different vegetables ranged from $1.33 \%$ to $1.91 \%$. The tannin content in S. nigrum 
Table 3. Proximate composition of different vegetables

\begin{tabular}{llllllll}
\hline \hline Proximate & Study sites & C. sativum & A. fistulosum & $\begin{array}{l}\text { T. foenum- } \\
\text { graecum }\end{array}$ & D. carota & R. sativus & B. rapa \\
& & & & & & \\
\hline & Site1 & $19.55 \pm 0.04$ & $20.56 \pm 0.08$ & $20.41 \pm 0.08$ & $18.24 \pm 0.2$ & $21.42 \pm 0.02$ & $21.38 \pm 0.21$ \\
Ash (\%) & Site2 & $22.46 \pm 0.04$ & $18.53 \pm 0.11$ & $23.66 \pm .02$ & $16.63 \pm 0.1$ & $15.79 \pm 0.05$ & $18.61 \pm 0.11$ \\
& Site3 & $18.63 \pm 0.05$ & $17.75 \pm 0.57$ & $16.41 \pm 0.07$ & $22.38 \pm 0.3$ & $17.35 \pm 0.04$ & $19.66 \pm 0.04$ \\
& Site1 & $19.38 \pm 0.01$ & $20.41 \pm 0.3$ & $20.51 \pm 0.02$ & $19.53 \pm 0.18$ & $21.31 \pm 0.03$ & $20.47 \pm 0.06$ \\
C.P (\%) & Site2 & $15.38 \pm 0.06$ & $26.19 \pm 0.7$ & $18.95 \pm 0.07$ & $23.38 \pm 0.26$ & $17.52 \pm 0.04$ & $22.16 \pm 0.03$ \\
& Site3 & $25.12 \pm 0.01$ & $22.33 \pm 0.4$ & $19.54 \pm 0.04$ & $21.65 \pm 0.13$ & $18.33 \pm 0.06$ & $20.34 \pm 0.08$ \\
& Site1 & $13.63 \pm 0.04$ & $13.42 \pm 0.09$ & $16.14 \pm 0.05$ & $15.32 \pm 0.2$ & $15.53 \pm 0.14$ & $16.33 \pm 0.09$ \\
C.F (\%) & Site2 & $16.29 \pm 0.01$ & $14.24 \pm 0.08$ & $14.33 \pm 0.04$ & $14.44 \pm 0.1$ & $13.41 \pm 0.13$ & $15.64 \pm 0.14$ \\
& Site3 & $12.81 \pm 0.02$ & $15.12 \pm 0.09$ & $14.71 \pm 0.05$ & $16.73 \pm 0.7$ & $14.32 \pm 0.17$ & $15.53 \pm 0.28$ \\
& Site1 & $0.68 \pm 0.01$ & $0.85 \pm 0.02$ & $0.95 \pm 0.02$ & $0.75 \pm 0.14$ & $0.79 \pm 0.4$ & $0.71 \pm 0.18$ \\
E.E (\%) & Site2 & $0.75 \pm 0.08$ & $0.69 \pm 0.08$ & $0.81 \pm 0.04$ & $0.84 \pm 0.17$ & $0.65 \pm 0.3$ & $0.76 \pm 0.17$ \\
& Site3 & $0.85 \pm 0.02$ & $0.73 \pm 0.09$ & $0.84 \pm 0.08$ & $0.81 \pm 0.14$ & $0.77 \pm 0.13$ & $0.67 \pm 0.07$ \\
\hline \hline
\end{tabular}

Table 4. Anti-nutrients composition of different vegetables

\begin{tabular}{|c|c|c|c|c|c|c|c|}
\hline Anti-nutrients & Study sites & C. sativum & A. fistulosum & $\begin{array}{l}\text { Trigonella } \\
\text { foenum-graecum }\end{array}$ & D. carota & R. sativus & B. rapa \\
\hline $\begin{array}{l}\text { Terpenes) } \\
(\mathrm{mg} / \mathrm{kg}\end{array}$ & $\begin{array}{l}\text { Site1 } \\
\text { Site2 } \\
\text { Site3 }\end{array}$ & $\begin{array}{l}138.33 \pm 1.4 \\
134 \pm 1.5 \\
128.33 \pm 1.7\end{array}$ & $\begin{array}{l}141.33 \pm 1.4 \\
148.67 \pm 0.9 \\
136.67 \pm 0.8\end{array}$ & $\begin{array}{l}146 \pm 1.2 \\
173 \pm 1.4 \\
191 \pm 1.5\end{array}$ & $\begin{array}{l}203 \pm 1.1 \\
174.67 \pm 1.8 \\
185 \pm 2.1\end{array}$ & $\begin{array}{l}215 \pm 1.15 \\
211 \pm 1.11 \\
201 \pm 2.01\end{array}$ & $\begin{array}{l}210 \pm 0.6 \\
193 \pm 0.6 \\
177 \pm 0.9\end{array}$ \\
\hline Tannins (\%) & $\begin{array}{l}\text { Site1 } \\
\text { Site2 } \\
\text { Site3 }\end{array}$ & $\begin{array}{l}1.65 \pm 0.1 \\
1.91 \pm 0.1 \\
1.74 \pm 0.2\end{array}$ & $\begin{array}{l}1.64 \pm 0.11 \\
1.79 \pm 0.14 \\
1.84 \pm 0.43\end{array}$ & $\begin{array}{l}1.54 \pm 0.14 \\
1.61 \pm 0.17 \\
1.50 \pm 0.17\end{array}$ & $\begin{array}{l}1.51 \pm 0.11 \\
1.45 \pm 0.12 \\
1.55 \pm 0.11\end{array}$ & $\begin{array}{l}1.72 \pm 0.17 \\
1.64 \pm 0.14 \\
1.33 \pm 0.23\end{array}$ & $\begin{array}{l}1.39 \pm 0.2 \\
1.64 \pm 0.4 \\
1.53 \pm 0.5\end{array}$ \\
\hline Alkaloids (\%) & $\begin{array}{l}\text { Site1 } \\
\text { Site2 } \\
\text { Site3 }\end{array}$ & $\begin{array}{l}1.85 \pm 0.12 \\
1.89 \pm 0.15 \\
1.94 \pm 0.17\end{array}$ & $\begin{array}{l}1.79 \pm 0.1 \\
1.77 \pm 0.8 \\
1.78 \pm 0.2\end{array}$ & $\begin{array}{l}1.85 \pm 0.11 \\
1.89 \pm 0.14 \\
1.91 \pm 0.11\end{array}$ & $\begin{array}{l}1.81 \pm 0.05 \\
1.87 \pm 0.01 \\
1.87 \pm 0.08\end{array}$ & $\begin{array}{l}1.78 \pm 0.21 \\
1.69 \pm 0.19 \\
1.66 \pm 0.18\end{array}$ & $\begin{array}{l}1.84 \pm 0.13 \\
1.76 \pm 0.17 \\
1.73 \pm 0.19\end{array}$ \\
\hline Saponins (\%) & $\begin{array}{l}\text { Site1 } \\
\text { Site2 } \\
\text { Site3 }\end{array}$ & $\begin{array}{l}3.44 \pm 0.11 \\
4.21 \pm 0.14 \\
4.55 \pm 0.15\end{array}$ & $\begin{array}{l}4.28 \pm 0.14 \\
5.69 \pm 0.11 \\
5.88 \pm 0.20\end{array}$ & $\begin{array}{l}5.87 \pm 0.08 \\
5.83 \pm 0.04 \\
4.97 \pm 0.01\end{array}$ & $\begin{array}{l}5.15 \pm 0.01 \\
6.13 \pm 0.08 \\
5.36 \pm 0.01\end{array}$ & $\begin{array}{l}6.28 \pm 0.11 \\
4.86 \pm 0.18 \\
5.13 \pm 0.14\end{array}$ & $\begin{array}{l}4.77 \pm 0.5 \\
4.87 \pm 0.3 \\
5.02 \pm 0.7\end{array}$ \\
\hline
\end{tabular}

and S. biafrae reported by Ajala (2009) was lower and that of $C$. aconitifolius reported by Aletor and Adeogun (1995) was higher as compared to present study (Table 4). Present contents of tannins were lower as compared to tannin values reported by Kayode et al. (2012). Ajiboye et al. (2013) reported lower concentrations of tannins than present findings. Except for tea, long and unnecessary utilization of vegetables containing high amount of tannins is not prescribed (Fasuyi, 2006). Tannins are water dissolvable phenolic mixes with an atomic weight $>500$ and exist in every single vascular plant. Tannin ties to proteins making them biounavailable (Sotelo et al., 1995).

Alkaloids. The alkaloids contents showed nonsignificant $(\mathrm{P}>0.05)$ result among all vegetables except C. sativum, T. foenum-graecum and $R$. sativus (Table
1). Kayode et al. (2012) recorded high contents of alkaloids as compared to the present contents of alkaloids. By and large, alkaloids have particular impacts on the focal sensory system (for instance, caffeine), particularly on the neural connections (the crevices between nerve cells) in the conductors of the sensory system. The general solvency of alkaloids in lipids is correlated in this sort of exploits (Lewis and ElvinLewis, 1998). Alkaloids are critical in pharmaceutical and constitute the majority of the profitable medications. They have checked physiological impact on human (Edeoga et al., 2005).

Saponins (\%). Saponins contents varied from 3.44\% to $6.28 \%$ among vegetables (Table 3 ). These values were higher when compared with the results from other works (Nkafamiya et al., 2010). The difference between 
saponins contents of different vegetables was significant $(\mathrm{P}<0.05)$ at all sites (Table 1). Chibueze and Akubugwo (2011) reported high contents of saponins as compared to present study. These anti-nutrients are of interest in light of the fact that they are critical both for the protection of plant and for human, as a class of cancer prevention agents. For example, saponins have been accounted for to have hypo-cholesterolic impact (Price et al., 1987) and this may help in the decrease of metabolic weight that would have been put on the liver while other anti-nutrients have anti-oxidation impact in animals (Enwere, 1998).

\section{Conclusion}

Highest concentration of $\mathrm{N}$ and $\mathrm{P}$ was found at site 3 suggested that wastewater is a good source of fertilizer. It is known that $\mathrm{N}$ and $\mathrm{P}$ are considered as the important macro nutrients that are required by crops for ample growth. Low ash content was found at site 3 in $T$. foenum-graecum which is usually an indicator of high nutrient quality of the selected vegetable. Proximate analysis revealed that the vegetable samples studied have great potentials as rich sources of essential nutrients like protein and fat when consumed.

\section{Acknowledgement}

The Higher Education Commission, Pakistan is acknowledged for providing the financial support through a research Scheme \# 2484/13 to the first and third authors. The Principal author also thankful to all the supports of this project and the referees for their positive input.

Conflict of Interest. The authors declare no conflict of interest.

\section{References}

A.O.A.C. 1990. Official Methods of Analysis of the Association of Official Agricultural Chemists. $15^{\text {th }}$ edition, Washington DC, USA.

Abara, A.E. 2003. Tannin content of Dioscorea bulbufera. Journal of Chemical Society of Nigeria, 28: 55-56.

Abidemi, T.A., Adebayo, O.J., Idowu, O., Agbotoba, M.O. 2009. Nutrient content and anti-nuritional factors in Shea butter (Butryospermum parkii) leaves. African Journal of Biotechnology, 8: 58885890.

Agbaire, P.O. 2011. Nutritional and anti-nutritional levels of some local vegetables (Vernomia anydalira, Manihot esculenta, Teiferia occidentalis, Talinum triangulare, Amaranthus spinosus) from Delta State, Nigeria. Journal of Applied Science and Environmental Management, 15: 625-628.

Ajala, L. 2009. The effect of boiling on the nutrients and anti-nutrients in two non conventional vegetables. Pakistan Journal of Nutrition, 8: 14301433.

Ajiboye, B.O., Ibukun, E.O., Edobor, G., Ojo, A.O., Onikanni, S.A. 2013. Qualitative and quantitative analysis of phytochemicals in Senecio biafrae leaf. International Journal of Inventions in Pharmaceutical Sciences, 1: 428-432.

Aletor, V.A., Adeogun, O.A. 1995. Nutrients and antinutrient components of some tropical leafy vegetables. Food Chemistry, 53: 375-379.

Aliyu, H.M. 2006. Proximate analysis of some leafy vegetables (Roselle, Jute and Bitterleaf). International Journal of Food and Agriculture Research, 3: 11-14.

Babayemi, O.J., Bamikole, M.A., Daodu, M.O. 2009. In vitro gas production and its prediction on metabolizable energy, organic matter digestibility and short chains fatty acids in some tropical seeds. Pakistan Journal of Nutrition, 8: 1078-1082.

Binta, R., Khetarpaul, N. 1997. Probiotic fermentation: Effect on anti-nutrients and digestability of starch and protein of indigenously developed food mixture. Journal of Nutrition and Health, 11: 139-147.

Butnariu, M., Chimie, G. 2006. Editura Mirton, Timioara, p. 225.

Chapman, H.D., Pratt, P.F. 1961. Methods of Analysis for Soil, Plants and Water. University California, Division of Agriculture Science, California, USA.

Chibueze, U., Akubugwo, E.I. 2011. Nutritive values and phytochemical contents of some leafy vegetables grown with different fertilizers. Agriculture and Biology Journal of North America, 2: 1437-1444. Doi:10.5251/abjna.2011.2.12.1437. 1444.

Cowan, M.M. 1999. Plant products as antimicrobial agents. Clinical Microbiolgy, 12: 564-582.

Duyff, R. 2002. American dietetic association's. $2^{\text {nd }}$ edition, Complete Food and Nutrition Guide, 2: 130-142.

Edeoga, H.O., Okwu, D.E., Mbaebie, B.O. 2005. Phytochemical constituents of some Nigerian medicinal plants. African Journal of Biotechnology, 4: $685-688$. 
Emmanuel, T.V., Jesse, T., Njoka, L.W., Catherine, L. H.V.M. 2011. Nutritive and anti-nutritive qualities of mostly preferred edible woody plants in selected drylands of Iringa district, Tanzania. Pakistan Journal of Nutrition, 10: 786-791.

Enwere, N.J. 1998. Foods of Plants Origin in Enugu Nsukka. A froobis publication, pp. 736-741.

Epstein, E., Taylor, J.M., Channey, R.L. 1976. Effects of sewage sludge compost applied to soil on some physical and chemical properties. Journal of Environmental Quality, 5: 422-426.

Eriyamremu, G.E., Adamson, I. 1994. Early changes in energy metabolism in rats exposed to an acute level of deoxycholate and fed a nigerian-like diet. Annals of Nutrition and Metabolism, 38: 174-183.

Fasuyi, A.O. 2006. Nutritional potential of some tropical vegetable leaf meals. Chemical characteristics and functional properties. African Journal of Biotechnology, 5: 49-53.

George, P.M. 2003. Encyclopedia of Foods and their Heating Power. Humane Press, Washington. 1: 526.

Harborne, J.B. 1973. Phytochemical Methods, pp. 49188. Chapman and Hall, London, UK.

Ibang, O.I., Okon, D.E. 2009. Minerals and anti-nutrients in two varieties of African pear (Dacryodes edulis). Journal of Food and Technology, 7: 106-110. 2009.

Isa, F.O., Adesala, S.O., Ojo, F.A. 2006. Effect of Maturity on the Nutritional Composition of Selected Green Leafy Vegetables. In: Proceedings of the $30^{\text {th }}$ Annual Conference of Nigerian Institute of Food Science and Technology ASCON Conference Centre, Badagry, Lagos.

Jackson, M.L. 1959. Soil chemical analysis. verlag: prentice hall, Inc., Englewood Cliffs, NJ. 1958, 498 S. DM 39.40, Journal of Plant Nutrition and Soil Science, 85: 251-252.

Kayode, A.O., Micheal, A.I., Adefolawe, A.A. 2012. Chemical and phytochemical profile of some uncommon green leafy vegetables consumed in south west, Nigeria. Journal of Environmental Science, Toxicology and Food Technology (IOSRJESTFT), 1: 22-26.

Kiziloglu, F.M., Turan, M., Sahin, U., Kuslu, Y., Dursun, A. 2008. Effects of untreated and treated wastewater irrigation on some chemical properties of cauliflower (Brassica olerecea L. var. botrytis) and red cabbage (Brassica olerecea L. var. rubra) grown on calcareous soil in Turkey. Agricultural Water Management, 95: 716-724.

Kjeldsen, F., Christensen, L.P., Edelenbos, M. 2003.
Changes in volatile compounds of carrots (Daucus carota L.) during refrigerated and frozen storage. Journal of Agriculture and Food Chemistry, 51: 5400-5407. DOI: 10.1021/jf030212.

Kochhar, S.L. 1981. Tropical Crops: A Textbook of Econmic Botany, Macmillian Publishers India Ltd, Delhi, India.

Lewis, W.M., Elvin-Lewis, M.P.F. 1998. Medical Botany, Plants Affecting Man's Health. Walter, H., Lewis, Memory, P.F., Elvin-Lewis, pp. 515, John Wiley and Sons, New York, USA.

Lola, A. 2009. The effect of boiling on the nutrients and anti-nutrients in two non conventional vegetables. Pakistan Journal of Nutrition, 8: 14301433.

Lucas, E.O. 1988. The potential of leaf vegetable in Nigeria. Outlook on Agriculture, 17: 163-168

Mensah, J.K., Okoli, R.I., Obaju-Obodo, J.O. 2008. Phytochemical, medicinal and nutritional properties of some green leafy vegetables. African Journal of Biotechnology, 2512: 758.

Mohammed, M.I., Sharif, N. 2011. Mineral composition of some leafy vegetables consumed in Kano, Nigeria. Nigerian Journal of Basic and Applied Science, 19: 208-211.

Nkafamiya, I.I., Osemeabon, S.A., Modibbo, U.U., Aminu, A. 2010. Nutritional status of non-conventional leafy vegetables, (Ficus asperifolia and Ficus sycomorus). African Journal of Food Science, 4: 104-108.

Obadoni, B.O., Ochuko, P.O. 2001. Phytochemical studies and comparative efficacy of the crude extracts of some homeostatic plants in Edo and Delta States of Nigeria. Global Journal of Pure Applied Science, 8: 203-208.

Osman, M.A. 2004. Chemical and nutrient analysis of baobab (Adansonia digitata) fruit and seed protein solubility. Plant Foods Human Nutrition, 59: 29-33.

Pandey, M., Abidi, A.B., Singh, S., Singh, R.P. 2006. Nutritional evaluation of leafy vegetable Paratha. Journal of Human Ecology, 19: 155-156.

Parveen, S., Nazif, W., Ahmad, M.F., Khan, A., Khattak, I.A. 2006. Nutritional status of different orchards irrigated with wastewater in district Peshawar. Journal of Agriculture and Biological Sciences, 1: 42-50.

Pearson, D. 1976. The Chemical Analysis of Foods, $7^{\text {th }}$ edition, pp. 27-72. Churchill Living Stone Edinburgh, London, UK. 
Price, K.R., Johnson, I.T., Federick, G.R., Malinow, M. 1987. The chemistry and biological significant of saponins in food and feeding stuffs. Journal of CRC Criticul Reviews in Food Science and Nutrition, 26: 127-135.

Roger, P., Elie, F., Rose, L., Martin, F., Jacop, S., Mercy, A.B., Felicite, M.T. 2005. Methods of preparation and nutritional evaluation of dishes consumed in a malaria endemic zone in Cameroon (Ngali II). African Journal of Biotechnology, 4: 273-278.

Rusan, M.J.M., Hinnawi, S., Rousan, L. 2007. Long term effect of wastewater irrigation of forage crops on soil and plant quality parameters. Desalination, 215: $143-152$.

Sarojini, T.R. 1998. Modern Biology. African- Feb Published Ltd. Book House Trust, 1 African-Feb Drive, P.M.B. Onitsha, Nigeria.

Sotelo, A.E., Contrerar, S., Flores, S. 1995. Nutritional value and content of antinutritional compounds and toxics in ten wild legumes of Yucatan peninsula. Plant Food Human Nutrition, 47: 115-123.

Steel, R.G.D., Torrie, J.H. 1980. Principles and Procedures of Statistics. A Biometrical Approach ( $2^{\text {nd }}$ edition), 4: 207-208, McGraw Hill, New York, USA.

Takebe, M., Ishihara, T., Matsuno, K., Fujimoto, J., Yoneyama, T. 1995. Effect of nitrogen application on the content of sugar, abscorbic acid, nitrate and oxalic acid in spinach (Spinacia oleracea L.) and Komatsun (Brassica campestris L.). Japanese Journal of Soil Science and Plant Nutrition, 66: 238-246.

Vadivel, V., Janardhanan, K. 2005. Nutritional and antinutritional characteristics of seven South Indian wild legumes. Plant Food and Human Nutrition, 60: 69-75. 